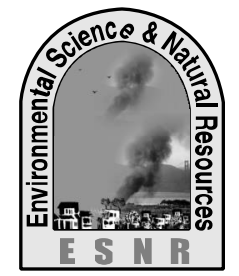

\title{
Waste Management at Jatiya Kabi Kazi Nazrul Islam University: Current Status and Future Options
}

\author{
M. N. H. Khan \\ Department of Environmental Science and Engineering, Jatiya Kabi Kazi Nazrul Islam \\ University, Trishal, Mymensingh-2220 \\ Corresponding author: hasannakibk@gmail.com
}

\begin{abstract}
The present study was conducted to measure waste production and its categories of JKKNIU, and find out its management options. Samplings were done in Student Hall, Teachersôand officersôdormitory, and central cafeteria of the University. Waste categories were organic, biodegradable, recyclable, inert materials etc. Major portion of the waste was organic biodegradable, about $65 \%$ of total waste. Waste are not being collecting and disposing properly due to unavailability of facilities, and this creating environmental pollution. Landfill, composting, and anaerobic digestion etc. could be use for proper management and to produce bio-gas and bio-fertilizer. Integrated waste management option would be better solution.
\end{abstract}

Key words: Biogas, Composting, Landfill, Solid waste, Waste Management

\section{Introduction}

Waste is produced by different human activities, like industrialization, urbanization, improving living standards etc. Urban population and industrialization have been increasing rapidly and these are creating a serious hassle on our natural resources, which is a big challenge for sustainable development. Disorganized management and dumping of waste is a noticeable cause of ruin of the environment in most cities.

Jatiya Kabi Kazi Nazrul Islam University (JKKNIU) is a fastest growing university where students as well as professionals are increasing. As the population is increasing in this campus waste production is also increasing day by day. These wastes are producing odor, environmental pollution, and it also potential threat to human health.

Currently JKKNIU is facing a solid waste management challenges. These challenges present numerous opportunities to improve methods in waste collection, transport, and disposal. There is no waste management facility in the JKKNIU campus. Waste are not being collecting properly and disposing in official dump sites due to no official sites. Uncollected waste has been recognized as the root of inferior environment such as scattered garbage, offensive odor; drain clogging, water pollution and mosquitoes. Given that solid waste management directly affects public health, land use, and the environment. Like other cities and university campus of Bangladesh, the majority of SW disposal takes place in open dumping grounds at JKKNIU campus. If this situation continues long time, it might cause serious health hazard to the residential and nonresidential staffs and students.

Different modern technologies and options have been introduce for the SW management properly such as incineration, land fill etc. Among the options anaerobic digestion technology uses microorganisms to consume organic waste (Bhada, 2007), producing a clean source of methane gas with limited contributions to global warming. This technology is widely used throughout the world as a waste management tool and a source of local, renewable energy (Rana, 2016). JKKNIU could choose one or more options as integrated solid waste management.

Considering the solid waste management issues at JKKNIU the present research was conducted to measure waste production and its categories of JKKNIU, and find out its management options in economic and profitable ways.

\section{Study area}

\section{Methods}

The present study was conducted at Jatiya Kabi Kazi Nazrul Islam University campus (Fig. 1), the fastest growing university in Bangladesh. It is located between $24^{\circ} 35^{\prime} \mathrm{N}$ latitude and $90^{\circ} 22^{\prime} \mathrm{E}$ longitude. It is situated in Trishal Upazilla of Mymensingh District. The JKKNIU campus is $96 \mathrm{Km}$ away from Dhaka the capital city of Bangladesh. 

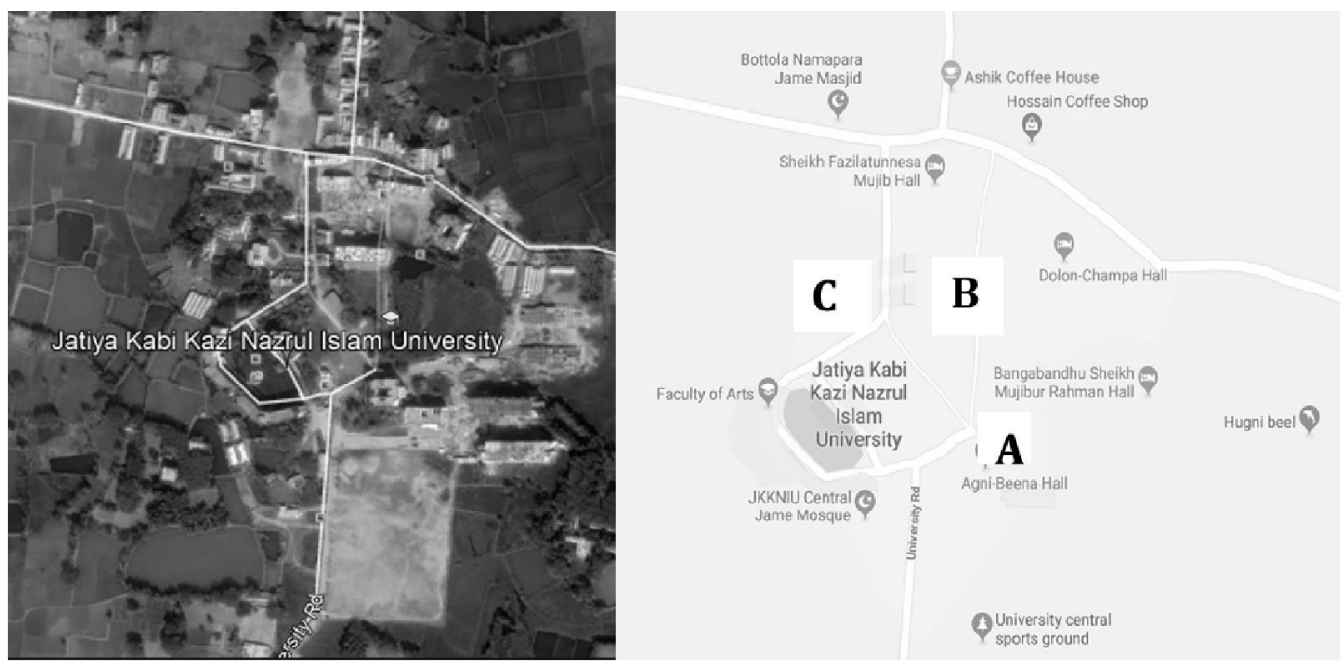

Fig. 1. Map showing the study area and sampling locations

\section{Sampling and analysis}

For the present study waste production data were collected from different places of the JKKNIU campus (Fig. 1). For the purposes of the research following locations/places were selected for collecting data.

A. Student hall (Agnibina Hall), where students produce different sorts of waste and the Dinning of the hall produce a large number of organic waste (Fig. 2).

B. Teachersôand officersôdormitory, where residents produce major portion of household waste (Fig. $3)$.
C. Central cafeteria of the University, where major portion of the waste especially organic waste produce form the cooking activities

Data was collected in daily basis, 24 hours interval from each location (Fig. 2 and Fig. 3). Wastes were stored in a bin for 24 hours, after that these wastes were measured digital electronics balance. Data were measured in Kilograms. Besides measuring, categories of wastes such as recyclable, biodegradable/nonbiodegradable, organic/inorganic etc. were also analyzed.

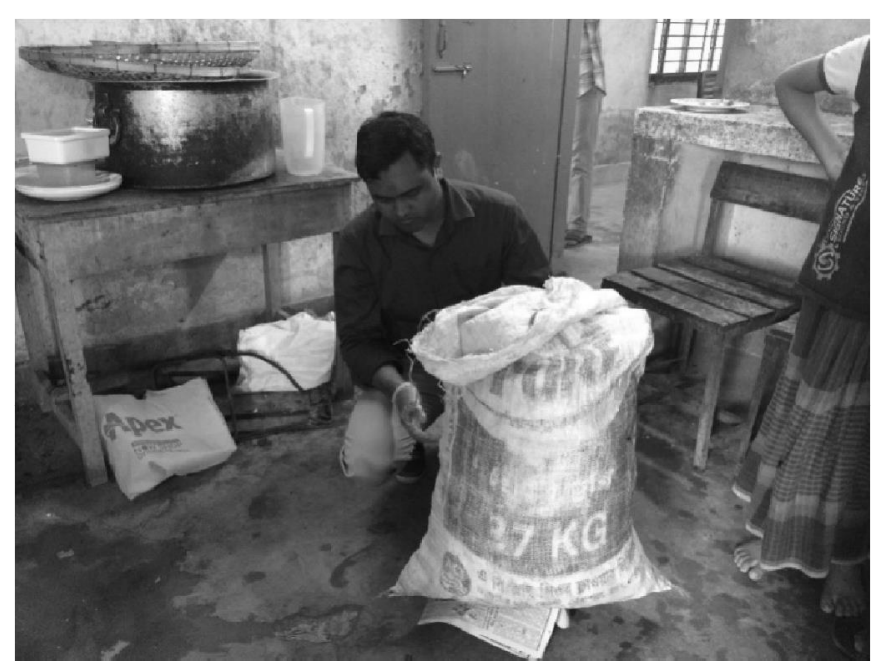

Fig. 2. Measuring waste from kitchen of Student Hall, Agnibina Hall 


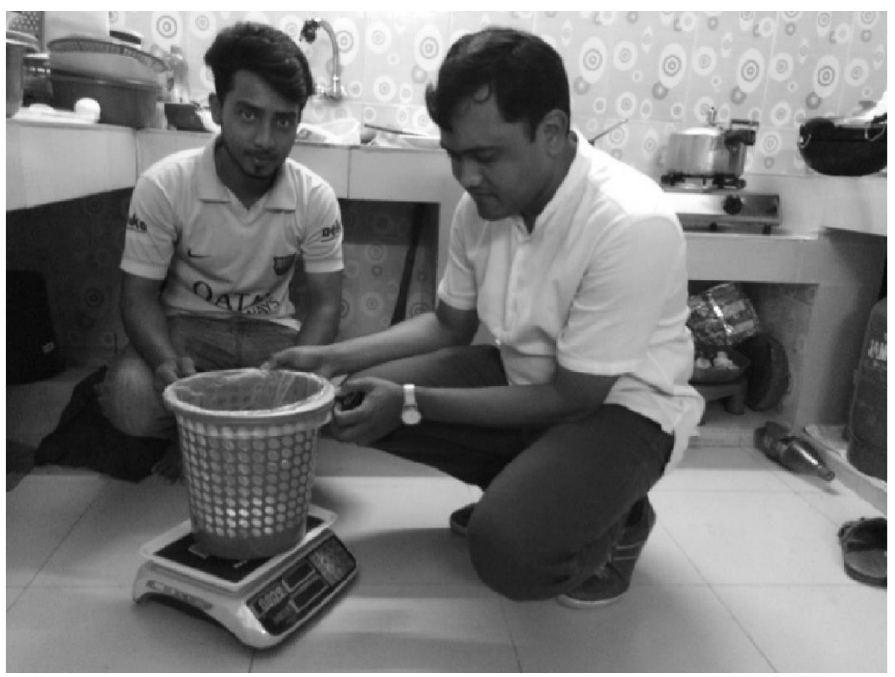

Fig. 3. Measure waste at residence, teachersôdormitory, of JKKNIU

\section{Results and Discussion}

\section{Waste generation at JKKNIU campus}

Population, student and staff, of the JKKNIU campus are increasing day by day due to expanding its academic departments and related activities. As the population is increasing the amount of waste production is also increasing. As students and staffs are living in the campus, consuming foods as well as different commodities and simultaneously producing different types of waste including biodegradable and

Table 1. Waste production in sampling places of JKKNIU

\begin{tabular}{|l|c|}
\hline \multicolumn{1}{|c|}{ Location } & $\begin{array}{c}\text { Volume of Waste } \\
\text { (Kg/day) }\end{array}$ \\
\hline $\begin{array}{l}\text { Teacher Dormitory } \\
\text { (Brahmmaputra Nikaton) }\end{array}$ & 40.4 \\
\hline Student hall (Agnibina Hall) & 17.2 \\
\hline Central Cafeteria & 39.1 \\
\hline
\end{tabular}

\section{Waste composition and categories of JKKNIU} campus

Composition of solid waste depends upon a number of factors, such as food habit, cultural tradition, socioeconomic and climatic condition. Composition of solid waste varies not only from city to city but even within the same city itself and also seasonally as well as University campus. The SW collected in JKKNIU campus consists of wet organics (primarily food waste), dry organics (straw, wood), inert materials (sand, soil, earth), and recyclables (plastics, metal, glass, paper). non-biodegradable. Waste produced not only from the residents but also from the non-residents who work in the campus during working hours as well as class periods. They produce waste in the classroom, office and canteen while taking foods. Wastes generated in the campus were measured in different places especially in the living places. The amount of the waste was a significant amount (Table 1). These wastes should manage properly; otherwise it will create a big problem in near future in terms of environmental pollution as well as human health.

\section{Organic materials}

The major component of waste generated in JKKNIU campus is organic material which produced as the residue of food and vegetables. Main part of this component comes from kitchen/household activity and a significant fraction comes from cafeteria. Organic matter can be divided into wet and dry organic matter. Wet organic matter consists of kitchen wastes, fruit wastes, flower wastes, green grass, and other small organic material that is less than 1ò in size. With regard to wet organic wastes, kitchen wastes constitute the majority of the waste, while green grass and flower waste make up less than $1 \%$ of organic waste. The largest components of dry organic wastes include dry grass and cotton waste. Around $65 \%$ of waste is organic materials at JKKNIU campus.

\section{Recyclable component}

Main recyclable part is paper product. Around 9.7\% of total waste is paper product which comes as backdated newspaper, paper used by different offices and 
students. Other recyclable components are plastic, leather, rubber, metals, glass, ceramics, electronics materials which are all together about $6.94 \%$. About $15 \%$ of total generated waste is recycled in JKKNIU campus.

\section{Inert materials}

The inert materials found in JKKNIU campus are sand, stone, silt, and bricks. A large proportion of these comes from road sweeping and illegal dumping of construction and demolition waste while construction activities and going on the campus.

\section{Current waste collection and disposal system of} JKKNIU

Currently there is no systematic or planned waste collection and disposal system in JKKNIU campus.
Waste are thrown here and there as soon as it produced. Recently, in 2018, some waste bins are set up in different locations of the campus. Though waste bins are setup but waste are not dumped properly to the bins (Fig. 4). Waste from these bins neither clean regularly nor treated properly. The garbage pass dump through residential areas creating odor, and air pollution problems along the way. Residents living near the bins often facing the problem of odors, vermin, and scavenging animals. As a result these waste produce odor and potential to create disease. To combat these problems, it is necessary to setting up a proper waste management system. Before setting up the system the university author should sprays disinfectants on the waste in regular interval so that it will unable to produce disease to the campus dweller.

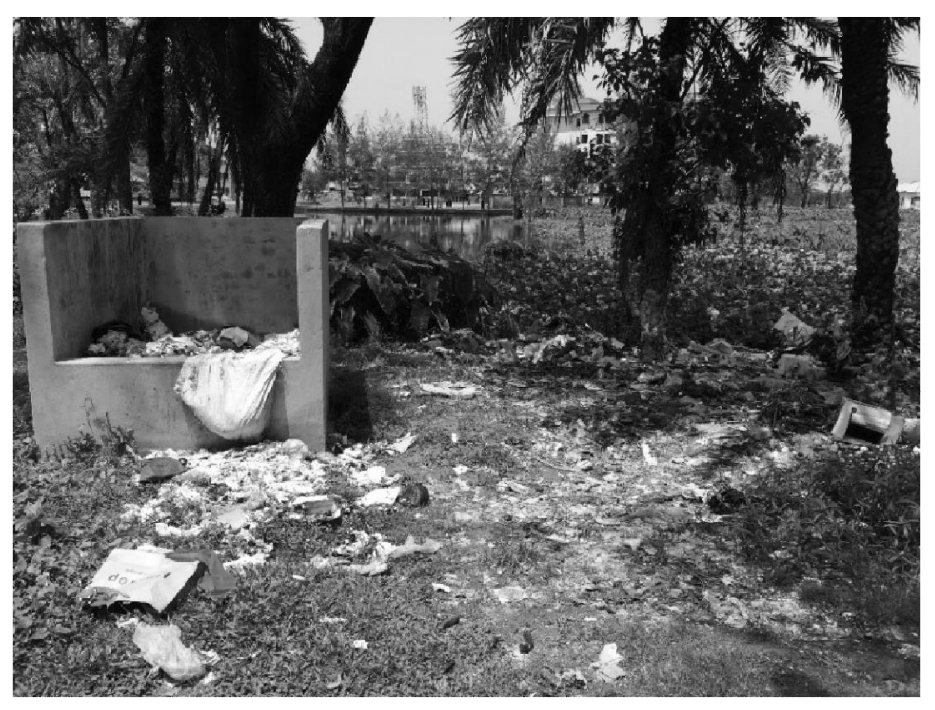

Fig. 4. Present waste disposal status at JKKNIU campus

Prospective waste management options for JKKNIU

There are different modern waste management options such as $3 R$ i.e. Reduce, Reuse, Recycle incineration, landfill, composting etc. Among them following options could be suitable for JKKNIU where its most portion of waste is biodegradable organic waste (Fig. $5)$. For better result it should choose integrated waste management system, the combination of two or more options.

\section{Waste reduce, reuse, recycle}

Waste reduction and reuse of products are both methods of waste prevention. They eliminate the production of waste at the source of usual generation and reduce the demands for large scale treatment and disposal facilities. Methods of waste reduction include production of less waste at the JKKNIU campus. For example reduce the use of paper in office and classroom by digitalizing. Reuses include the use of waste paper which is one side blank and also use other materials. Recycling refers to the removal of items from the waste stream to be used as raw materials in the manufacture of new products. Plastic, Paper, Electronic waste of the campus could be selling as raw materials. These raw materials are then used in the production of new products. 


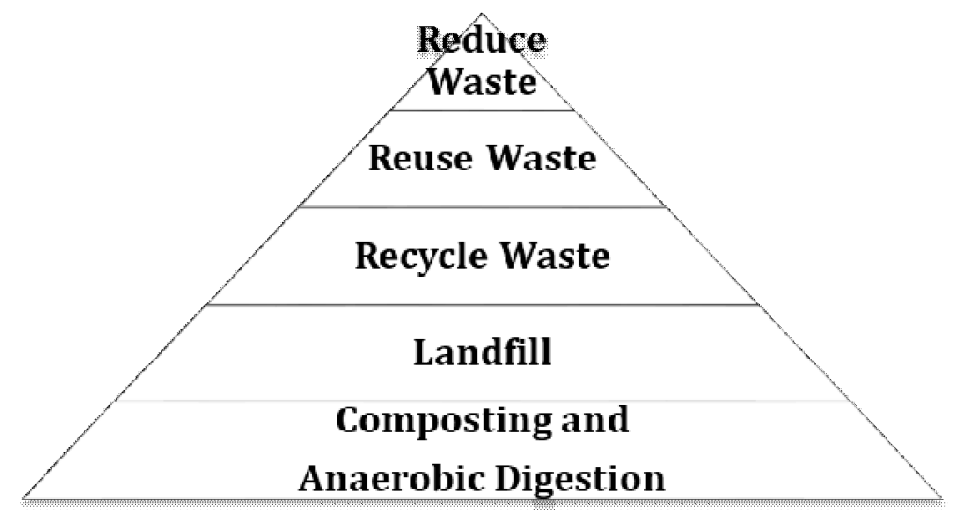

Fig. 5. Proposed solid waste management options at JKKNIU campus

\section{Landfill}

Sanitary Landfills are designed to greatly reduce or eliminate the risks that waste disposal may pose to the public health and environmental quality. They are usually placed in areas where land features act as natural buffers between the landfill and the environment. A landfill is divided into a series of individual cells and only a few cells of the site are filled with trash at any one time. This minimizes exposure to wind and rain. The daily waste is spread and compacted to reduce the volume, a cover is then applied to reduce odors and keep out pests. When the landfill has reached its capacity it is capped with an impermeable seal which is typically composed of clay soil. Some sanitary landfills are used to recover energy. The natural anaerobic decomposition of the waste in the landfill produces landfill gases which include Carbon Dioxide, methane and traces of other gases. Methane can be used as an energy source to produce heat or electricity. Thus some landfills are fitted with landfill gas collection (LFG) systems to capitalize on the methane being produced. The process of generating gas is very slow, for the energy recovery system to be successful there needs to be large volumes of wastes. LFG contains roughly 50 to 55 percent methane and 45 to 50 percent carbon dioxide, with less than 1 percent non-methane organic compounds and trace amounts of inorganic compounds (Rana, 2016). Therefore it has a great opportunity to produce gas as energy while landfill of solid waste of JKKNIU where most of the SWs are biodegradable organic waste.

\section{Composting}

Composting is a simple way to convert organic material to carbohydrate (aerobic process) and gases (anaerobic process). In aerobic process, mainly compost fertilizer is produced and anaerobic process different gases are produced such as methane, carbon di-oxide, sulpher di-oxide etc. In composting methods organic matters are decomposed by the action of microorganisms and small invertebrates. There are a number of composting techniques being used today. These include: in vessel composting, windrow composting, vermicomposting and static pile composting etc. The process is controlled by making the environmental conditions optimum for the waste decomposers to thrive. The rate of compost formation is controlled by the composition and constituents of the materials i.e. their Carbon/Nitrogen $(\mathrm{C} / \mathrm{N})$ ratio, the temperature, the moisture content and the amount of air. Composting would be a great option for waste management for JKKNIU campus where major portion of its wastes are biodegradable organic waste.

\section{Anaerobic digestion}

Anaerobic digestion is a biological process where organic material is decomposed by anaerobes, variety of microbes, in absence of air to yield methane rich biogas. The anaerobic respiration results in the formation of Carbon Dioxide and methane. In addition to generating the humus which is used as a soil enhancer. Anaerobic Digestion is also used as a method of producing biogas which can be used to generate electricity. Anaerobic process is more advantageous than aerobic process in solid waste treatment because of high degree of waste stabilization, low production of excess biological sludge, low nutrient requirement and high production of methane gas as a useful by-product (Mc Carty, 1964). However, the bio gas production is mainly depends on different parameters such as substrate concentration, $\mathrm{pH}$ of the substrate, temperature, stirring speed $\mathrm{C} / \mathrm{N}$ ratio etc. It has been reported that the presence of some organic material may enhance the biogas production as the enzymatic part of the concern bacteria is activated (Rana, 2016). Anaerobic digestion 
would be a good waste management practice for

\section{Production of bio-gas and bio-fertilizer from bio- degradable waste}

As anaerobic bacteria digest organic waste, they produce a mixture comprised mostly of carbon dioxide and methane called ñbiogas.ò The percentage of methane contained within biogas can vary dramatically based on a myriad of factors including the type of feedstock digested, the type of bacteria used, the design of the digesters, and the retention time for the slurry. The amount of gas typically ranges between 50ï 70\% (Klinkner, 2014). Average biogas production at an anaerobic digestion facility falls between 0.2 and 0.3 standard cubic meter per wet kilogram of waste

\section{JKKNIU.}

(Rana, 2016). The methane produced by anaerobic digestion may be used as an energy source in several ways such as production of electricity. It has potential options to produce biogas from the waste generated in the JKKNIU campus. And this biogas could be supply to the resident of the campus as well as could be produce electricity (Fig. 6). Bi-Product, the slurry, will dispose through bottom of tank after collecting the gas into gas reservoir. The dispose digested uses as compost fertilizer which will add revenue. Produced bio-fertilizer from the waste could be sell to the farmers of the adjacent areas of the JKKNIU campus.

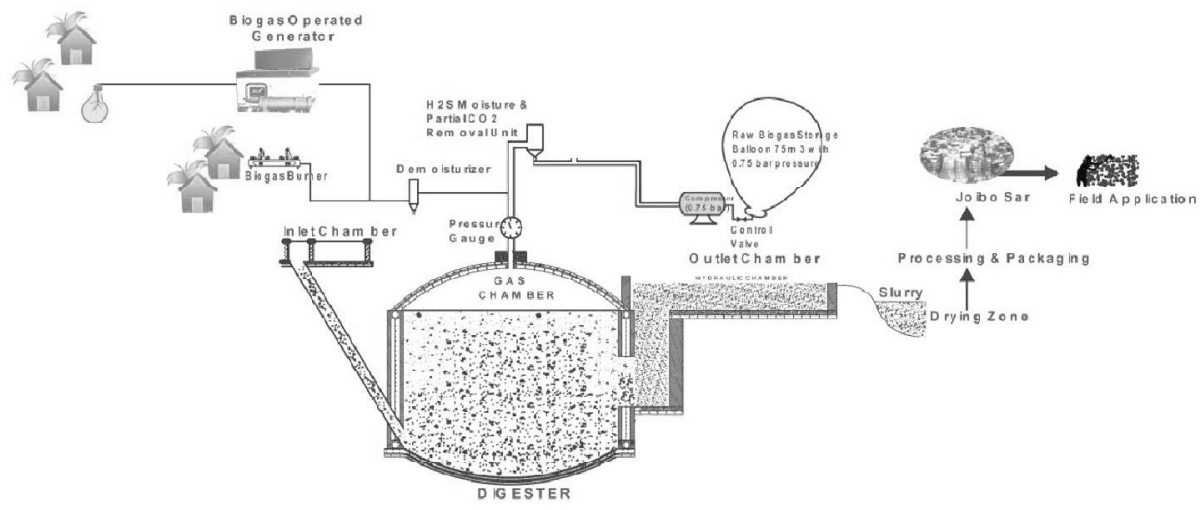

Fig. 6. Schematic diagram of biogas and bio-fertilizer production

\section{Conclusions}

Jatiya Kabi Kazi Nazrul Islam University is facing significant challenges for solid waste management. Solid waste generation in the campus will be increase day by day with the increasing of students and staffs of the University. For the safe of the health of student, staff as well as protect environmental pollution of the campus it need immediate steps to manage solid waste properly. It has a good opportunity to produce bio-gas and bio-fertilizer from the solid waste of the campus and profit could be earned from selling gas and fertilizer byproduct. It need further research in terms of future work before making a final decision/choosing the options for waste management. Integrated waste management would be better options for waste management of JKKNIU campus.

\section{Acknowledgements}

This research was funded by the Jatiya Kabi Kazi Nazrul Islam University in the fiscal year 2017-2018 (Representative researcher: Md. Nakibul Hasan Khan).
The author is very much grateful for this financial assistance.

\section{References}

Bhada P., 2007, Feasibility analysis of waste to energy as a key component of integrated solid waste management in Mumbai, Department of Earth and Environmental Engineering Fu Foundation School of Engineering and Applied Science Columbia University.

Klinkner B. A., 2014, Anaerobic Digestion as a Renewable Energy Source and Waste Management Technology: What Must be Done for This Technology to Realize Success in the United States? 9U. MASS. L. REV. 68, UMass Law Review.

Mc Carty P.L., 1964, Anaerobic Waste treatment fundamentals, Public Works 95, 91,123.

Rana M. S., 2016, Feasibility Study of Waste to Energy and Power Generation of Dhaka City, MS Thesis, University of Dhaka. 